\title{
Big 4 and non-Big 4 Audit Production Costs: Office Level Audit Technology and the Impact on Audit Fees
}

\author{
LOUIS-PHILIPPE SIROIS*, HEC Montréal \\ SOPHIE MARMOUSEZ, HEC Montréal \\ DAN A. SIMUNIC, University of British Columbia
}

Preliminary Draft, This version:

May, 2011

\begin{abstract}
This paper is based on Louis-Philippe Sirois's dissertation at the University of British Columbia. We are grateful for comments from workshop participants at HEC Montréal. Dan Simunic acknowledges financial support from the Social Sciences and Humanities Research Council of Canada.
\end{abstract}

* Corresponding author: Tel. (514) 340-6730, louis-philippe.sirois@ hec.ca 


\title{
Big 4 and non-Big 4 Audit Production Costs: \\ Office Level Audit Technology and the Impact on Audit Fees
}

\begin{abstract}
We empirically evaluate the degree to which Big 4 auditors achieve economies of scale resulting from investments in audit technology at the local U.S. office level and, more importantly, determine how this affects audit pricing differences between Big 4 and nonBig 4 auditors. Focusing on the U.S. audit market for small to medium sized public companies, we argue and find that, relative to non-Big 4 auditors, Big 4 audit firms benefit from economies of scale at the local office level. In turn, this results in decreasing Big 4 audit fees in local market size, relative to non-Big 4 audit fees (i.e., decreasing Big 4 premium). Our results are consistent with Big 4 audit firms engaging in greater audit technology investments at the local office level in order to enhance audit efficiency, as argued by Sirois and Simunic (2010). Overall, our results support the view that the U.S. audit market remains competitive, despite the high level of market concentration.
\end{abstract}




\section{INTRODUCTION}

Differences between Big 4 and non-Big 4 auditors are well established in the auditing literature. Most notably, the empirical evidence strongly suggests that Big 4 auditors are of higher quality (real and/or perceived) and that they command higher audit fees (e.g., Francis (2004); Watkins, Hillison, and Morecroft (2004)). Yet, surprisingly, little is known about actual differences which may exist between Big 4 and non-Big 4 firms' audit production processes, and more specifically, differences in cost structures. The objective of this study is to address this last point directly. We build on intuition from the industrial organisation literature as illustrated in Sirois and Simunic (2010) to empirically evaluate the degree to which Big 4 auditors achieve production efficiency gains and economies of scale resulting from investments in audit technology at the local office level and, more importantly, determine how this affects audit pricing differences between Big 4 and non-Big 4 auditors.

The primary objective of this paper is to provide a formal test of the theory developed in Sirois and Simunic (2010). They argue that Big 4 and non-Big 4 audit firms fundamentally differ with respect to their investment strategies in audit technology ${ }^{1}$, with Big 4 audit firms choosing to invest more in audit technology as a differentiation strategy to enhance the relative value of their audits through greater audit quality, real and/or perceived, and/or audit production efficiency gains. Consequently, differences between Big 4 and non-Big 4 audit quality and audit fees vary according to the relative level of such investments which, in turn, results in the well documented Big 4/non-Big 4 dichotomy and dual structure of the industry. Sirois and Simunic (2010) further show that because investments in audit technology are strategic firm decisions (i.e., endogenous), the level of such investments for Big 4 audit firms is increasing in market size. Therefore, in a single country setting where Big 4 and non-Big 4 audit quality is expected to remain mostly constant across local markets, we posit and find that, ceteris paribus, Big 4 audit

\footnotetext{
${ }^{1}$ As in Sirois and Simunic (2010), we broadly define audit technology as investments that enhance real and/or perceived (e.g., advertising) quality of audits, and/or improve audit production efficiency. In the short term, audit technology is a fixed input in the audit production process while audit effort (i.e., audit hours) is a variable input.
} 
fees will be decreasing relative to non-Big 4 audit fees ${ }^{2}$. In other words, we predict and find that Big 4 audit fee premium is decreasing in local market size. We test this hypothesis in the U.S. audit market for small to medium sized public companies.

Overall, our analysis lends support to the notion that audit technology is a key input of the audit process, and more so for the Big 4 audit firms which stand to achieve greater economies of scale. In turn, this illustrates the need to consider (or control for) factors which may affect the relative uses of audit technology when exploring differences between Big 4 and non-Big 4 audit quality and fees. Indeed, these are commonly argued to result rather from differences in Big 4 and non-Big 4 audit effort (e.g., Choi et al. (2008)) and/or independence (e.g., Choi et al. (2010)). And while it is implicitly assumed in the literature that Big 4 and non-Big 4 auditors may employ different audit technologies, with Big 4 auditors employing possibly "superior" technology, why and how technologies differ and the process by which Big 4 and non-Big 4 auditors develop different audit technologies is unclear and anecdotal.

Indeed, although claims that the Big 4 audit firms benefit from economies of scale are common (e.g., United States General Accounting Office (GAO) 2008)), the empirical evidence of the impact of scale economies on audit pricing is limited. Early studies on audit fees have looked at differences in Big 4 and non-Big 4 audit fees across the large and small auditee market segments at the national audit market level (e.g., Simunic (1980); Francis and Stokes (1986); Palmrose (1986)). Generally, the evidence has been associated with product differentiation (i.e., higher Big 4 audit quality) and non-Big 4 diseconomies of scale in the large client market segment. However, our research design is well motivated by theory and differs significantly from earlier studies in that we investigate the existence of scale economies at the local market level; contributing to the

\footnotetext{
${ }^{2}$ That is, given auditor type, the level of audit quality is expected to remain mostly constant across local markets. However, between auditors of different types the level of audit quality may well differ. As we explain in the next section, investments in audit technology by Big 4 local audit offices are expected to be predominantly designed to improve production efficiency and therefore allow Big 4 audit firms to price their audits more competitively/aggressively as market size increases. We do not claim, however, that Big 4 audit fees are lower in magnitude than those of non-Big 4 auditors. Rather, it is the differential between the two that is decreasing in market size (i.e., lower premium).
} 
growing literature investigating audit and auditor characteristics at the local office level ${ }^{3}$. Our study is the first, to our knowledge, to illustrate that Big 4 local offices benefit from economies of scale and that this translates in costs savings to audit clients. Our test results also demonstrate that Big 4 economies of scale are, at least in part, driven by increasing returns to scale for the Big 4 auditors and confirm that some investment decisions that impact audit firms' pricing strategies are undertaken at the local office level where audit contracting occurs.

We are aware of only one published study which tests for the possibility that local auditor offices may benefit from economies of scale by investigating the relation between audit fees and local auditor office size (Choi et al. (2010)). Yet, Choi et al. (2010) find that audit fees are in fact increasing in local office size and argue that this is consistent with increasing audit quality rather than the presence of economies of scale. Hence, our results appear to contradict theirs, although we motivate our hypothesis from a different theory and our research designs differ slightly ${ }^{4}$. We argue later, however, that their research design may not appropriately control for specific factors, namely time and return to scale differences between Big 4 and non-Big 4 firms which may bias in favour of their results. In any case, we believe this suggests that more research is necessary into how audit fees are affected by local market characteristics, among them market size.

Our main contribution is to provide formal evidence supporting Sirois and Simunic (2010). As such, we contribute to our understanding of the audit industry, its dynamics and what drives the Big 4/non-Big 4 dichotomy by exploring the role audit technology plays. This is important in light of recent concerns raised by regulatory agencies, business

\footnotetext{
${ }^{3}$ Previous studies compared average Big 4 audit fees (Big 8 back then) to non-Big 4 audit fees on a sample of audits from small and large auditees pooled across local markets. As such, only "national wide" differences between Big4 and non-Big 4 auditors in the small and large auditee market segments were observed. The research design used assumed (and effectively forced) any possible scale economies were "shared" uniformly across all local offices and failed to capture variations in local market investment opportunities which possibly lead to scale economies (at the office level). In essence, only two levels of operational scale were considered (i.e., Big vs. non-Big), thus offering a weak setting for testing the existence of scale economies. By focusing on local offices, our research design also mitigates the opposing, yet simultaneous, effects product differentiation and differences in scale economies may have on audit pricing. This is explained further in the second section.

${ }^{4}$ Unreported statistics from our sample confirm that office size is highly correlated with market size, and even more so with Big 4 office size.
} 
associations and private interest groups over the high level of market concentration (i.e., Big 4 market power) and its potential adverse impact on the audit product, innovation and audit fees ${ }^{5}$. Although recent reports by the GAO suggest that the high level of market concentration has not adversely impacted audit quality and fees, the GAO stresses that its "(...) findings should not necessarily be viewed as definitive or as proof that the market for audit services is competitive" (GAO (2008, p. 94)). The general consensus is that more research is needed to better understand the dynamics of the audit industry.

The remainder of this paper is organised as follows: Section 2 presents a review of prior research investigating the existence of economies of scale in the auditing industry, along with the hypothesis for this study; Section 3 describes the empirical research design; Section 4 presents the data and empirical results and we conclude with Section 5.

\section{HYPOTHESIS DEVELOPMENT}

Sirois and Simunic (2010) discuss a model of audit firm competition where both audit quality and audit firm size are endogenous. Based on this model, they predict how certain market characteristics, namely market size and investor protection regime, affect the structure of the auditing industry and differences between Big 4 and non-Big 4 audit quality and fees. In essence, they argue that Big 4 and non-Big 4 auditors fundamentally differ with respect to their investment strategies in audit technology, with Big 4 auditors competing on audit value (i.e., quality-price ratio) through fixed investments in technology, the level of which is increasing in both market size and the degree of investor protection.

The intuition behind their framework is straightforward. To start, they note that an audit firm's output, including the real and/or perceived level of quality associated with its audits, essentially involves a combination of costly production inputs, namely audit effort

\footnotetext{
5 GAO (2003, 2008); The American Assembly (2005); Audit and Assurance Faculty (ICAEW) (2005); London Economics (2006); Oxera Consulting (2006, 2007); U.S. Chamber of Commerce (2006, 2007); Commission of the European Communities - Directorate General for Internal Market and Services (ECDG) (2008) and Advisory Committee on the Auditing Profession (ACAP) (2008).
} 
(e.g., audit hours) and audit technology. In the short term, audit effort is considered a variable input while audit technology, which represents mostly auditor "know-how" or competence, is a fixed input. That is, the level of auditor "know-how", competence and other technologies employed by an audit firm results from past investment decisions.

Sirois and Simunic (2010) argue that Big 4 audit firms can, and choose to, improve their contribution margins through fixed (capital) investments in audit technology. These investments increase client-firms "willingness-to-pay" (i.e., obtain higher prices) by enhancing the perceived quality of their audits through fixed investments in advertising ${ }^{6}$, or by improving true audit quality through R\&D activities, training, etc. (i.e., product innovations) $)^{7}$. Moreover, audit firms can invest in technology, IT equipment, training, standardized audit programs, etc. to improve their production and organizational processes in an effort to lower marginal costs and ultimately audit fees (i.e., process innovations). These investments in competitive capability are endogenous in the sense that they result from individual firms' business strategy. The more a firm chooses to invest, the greater the (positive) impact on its contribution margin. Yet, the costs of such investments are fixed and do not depend on the level of output. Consequently, the benefits from fixed investments are increasing in the level of output and firms therefore have greater incentives to undergo such investments as market size increases. In other words, technology investing audit firms have greater opportunities to exploit scale economies in larger markets.

In their work, Sirois and Simunic (2010) further illustrate how Big 4 and non-Big 4 firms differ in their respective strategies over investments in audit technology and, under a set of very simple assumptions, demonstrate how this leads to the dual market structure characteristic of the audit industry: a highly concentrated market with few high-quality suppliers (i.e., Big 4s) and a large number of small lower-quality auditors (i.e., non-Big 4s). The Big 4 audit firms' dominance is a consequence of the higher value of their audits

\footnotetext{
${ }^{6}$ Hay and Knechel (2009) find evidence consistent with the notion that audit firms engage in "qualitybased" (fee increasing) advertising and observe that this is more prominent for Big 4 audit firms.

${ }^{7}$ The assumption here is that client-firm value is increasing in audit quality, where audit quality refers to the auditor's ability to detect material misstatements and is a function of audit effort and audit technology.
} 
(i.e., higher quality-price ratio) which comes from the greater use of audit technology by these firms. Moreover, because this ratio is driven by investments in audit technology, it is increasing in market size for Big 4 firms relative to non-Big 4 firms who follow a noninvesting strategy ${ }^{8}$. This helps explain why Big 4 auditors continue to control significant market shares even in very large markets that can accommodate many suppliers.

Yet, the nature of investments in audit technology is a function of how markets are defined. Stated differently, whether investments result in "product innovation" or "process innovation" depends on the level at which they are planned and incurred (i.e., local office, national partnership or global network). In this study, we focus on local offices in a single country, the U.S. We conjecture that, for the most part, the benefits associated with investments at the global network and U.S. partnership level are likely shared mostly uniformly across all offices. Consequently, these investments would have little, if any, differential impact across local U.S. offices. Rather, we focus on investments made at the local office level. We argue below that these investments are predominantly planned to enhance audit production efficiency. That is, local Big 4 fixed costs investments are incurred mostly to lower marginal production costs and thus allow Big 4 audit firms to compete more aggressively on price. Big 4 offices therefore increase the value of their audits as market size increases (i.e., increasing quality-price ratio in market size) and leads to our research hypothesis:

HyPOTHESIS 1: Ceteris paribus, Big-4 audit fees are decreasing in market size, relative to Non-Big-4 firms.

Hypothesis 1 is essentially a reformulation of Prediction 4 from Sirois and Simunic (2010), adapted to our single country setting. To motivate our hypothesis we note that within a single country setting, local member practices of a given Big 4 national network are organized as a national partnership and share a common brand name. As such, not only are legal and regulatory requirements the same for all offices, but the legal and

\footnotetext{
${ }^{8}$ That is, non-Big 4 auditors invest, for the most part, the exogenously required minimum amount in audit technology to meet professional and legal standards rather than pursuing a strategy heavily reliant on audit technology investments.
} 
reputational costs these face are equal (i.e., same legal regime) ${ }^{9}$. Moreover, the reputation for audit quality is mostly associated with the national brand-name and thus constant across all local offices.

In fact, there is little incentive for a local practice to invest in audit technology to enhance the quality of its audits above the partnership's standard given that it is less likely to be perceived by audit clients and valued accordingly. Likewise, there is a strong incentive for members to constitute a national partnership with strong oversight powers of local members' auditing practices to ensure uniform (partnership-level set minimum) audit quality. In this case, partnership level audit standards and quality controls offer two significant benefits. First, it limits the "free rider" problem within the partnership. Second, it adds value to the audits of all member offices by lowering transaction costs as there is less information asymmetry over the true quality of the audits provided by local offices ${ }^{10}$. Hence, the quality of Big-4 audits is expected to remain constant across all local markets.

On the other hand, because Big 4 audit quality and reputation is mostly set at the national level, price competition becomes more important at the local office level. Yet, as local market size increases, local Big 4 offices still find it optimal to pursue an investment strategy in audit technology as a means to enhance the value of their audits. Consequently, local Big 4 office investments in audit technology predominantly involve process innovation targeted to lower marginal costs. Investments in audit production capacity are one example ${ }^{11}$.

Our line of reasoning differs, however, from that of Francis and Yu (2009) and Choi et al. (2010) (the former study directly focuses on Big 4 auditors, while the latter does not

\footnotetext{
${ }^{9}$ State specific legislation and professional licensing requirements are not expected to differ significantly.

${ }^{10}$ This has benefits to both external clients (i.e., auditee) and "internal" clients (i.e., audits involving multiple offices). The latter point would more appropriately be associated to process innovation as it facilitates the conduct of an audit.

${ }^{11}$ Office production capacity is highly driven by local hiring decisions and while audit labour is thought of a variable input, "capacity slack" in audit labour is itself akin to a fixed cost investment. In other words, audit labour can be more appropriately defined as a quasi-fixed cost. Investing in capacity slack is a form of process innovation as it allows greater flexibility and facilitates the production and delivery audits.
} 
make that distinction). Indeed, these two studies conjecture that audit quality is increasing in office size, which is highly correlated with market $s^{12} \mathrm{e}^{12}$. Moreover, they report evidence consistent with their conjecture. Nonetheless, these results need not be contradictory to our study. First, if audit quality is indeed increasing in office size (and likely more so for Big 4 audit firms as reported by Francis and Yu (2009)), this would still imply that Big 4 audit value (i.e., quality-price ratio) is increasing in market size ${ }^{13}$. If anything, these results bias strongly against our hypothesis, making our results all the more noteworthy. Second, note that we focus exclusively on the small to medium sized public company market segment where price, rather than quality, is likely to be a more important factor in auditor selection, which creates greater incentives for local offices to lower audit fees ${ }^{14}$.

\section{METHODOLOGY AND RESEARCH DESIGN}

Big 4 local offices are expected to achieve greater production efficiency and benefit from greater economies of scale as local market size increases. Here we define local audit markets on two dimensions: first, on a geographical dimension; and second, on the basis of client-firm size ${ }^{15}$. Furthermore, we only consider the U.S. audit market. As discussed

\footnotetext{
${ }^{12}$ Importantly, note that we take market size as our test variable since it is truly exogenous and more likely an explanatory factor of audit quality and/or fees. Office size, rather, is more likely a consequence of audit quality and pricing decisions. This is especially problematic when estimating the relation between audit fees and office size given that office size is measured in terms using audit fees. This is the case in Choi et al. (2010).

${ }^{13}$ There are several reasons why this is possible and nonetheless consistent with the national brand name argument we present. First, audit technology investments at the national (and even international) level may not spread uniformly across local offices. For example, specialized partnership wide support groups set up to assist local audit teams on complex accounting and auditing issues tend to be centralized at national and regional administrative offices, usually the largest offices operating in the largest markets (e.g., New York head offices of the Big 4 audit firms). Because of the proximity of such (human) capital investments, the associated benefits may disproportionally spillover more to the largest offices where these "national-quality centers" are located. Second, investments in process innovation and product innovation are not entirely independent and likely complementary.

${ }^{14}$ There is anecdotal evidence suggesting that Big 4 audit firms are significantly discounting rates to smaller audit clients in an effort to regain market shares in the small to medium public company market segment lost to non-Big 4 auditors in the wake of Sarbanes-Oxley (Cole (2008)).

${ }^{15}$ Although the national U.S. audit market is often divided into submarkets based on client-firm industries (e.g., Eichenseher and Danos (1981); Danos and Eichenseher (1982, 1986); GAO (2003, 2008)), partitioning by client-firm industry as well is not appropriate here. First, while production efficiencies and economies of scale can likely be achieved from specialisation, the object of this study is to determine if more general economies of scale are attained at the local office level, irrespective of industry specialisation.
} 
previously, focusing only on a single country ensures that institutional and other country specific factors known to affect audit fees are held constant (e.g., Taylor and Simon (1999) and Choi et al. (2008)). Moreover, the size of the U.S. market implies that subdividing it at the local level is possible, resulting in a fair number of local markets of varying sizes.

\section{Local Market Definition: Geographical Dimension}

Local audit markets are defined initially on a geographical dimension, with markets corresponding to specific Metropolitan Statistical Areas (MSA) defined in the 2000 U.S. Census $^{16}$. This is consistent with Penno and Walther (1996) who compare the relation between market concentration and local market size for accounting, advertising and law firms in the U.S, as well as studies on audit and auditor characteristics at the local office level (e.g., Francis and Yu (2009); Choi et al. (2010)). Auditor engagement offices are associated to a given MSA based on the city-state location of the engagement office as reported in the auditor report (i.e., contracting office). This information is obtained from the Audit Analytics database.

\section{Local Market Definition: Large vs. Small to Medium Sized Companies}

Large and small to medium sized companies present different characteristics that impact both the relative demand for audit quality (e.g., Big 4 vs. non-Big 4 audits) and how audits are produced within each market segment. A recent GAO survey documents that the Big-4 audit firms' dominance of the audit market varies greatly across segments of

In fact, there are likely strong "spillover" effects between technological investments in different client-firm industries in the same cities. Second, partitioning markets both geographically and by client-firm industry would reduce the power of the tests as many markets would end up with too few observations to accurately draw any inferences about production costs. Finally, the measure of size for a jointly defined city-industry market would not be as objective and reliable as a simple measure of geographical market size based on, for example, population or local GDP. Nonetheless, to control for potential client-firm industry effects we exclude financial institutions (SIC 6000-6999) from the sample. This is common in the literature, although unreported results show that the conclusions of this study are unaffected by the inclusion or exclusion of these firms. We also control for specific industry effects in the audit fee model presented below.

${ }^{16}$ A metropolitan area contains a core urban area of 50,000 or more population. Each metropolitan area consists of one or more counties and includes the counties containing the core urban area, as well as any adjacent counties that have a high degree of social and economic integration (as measured by commuting to work) with the urban core. See http://www.census.gov/population/www/estimates/metroarea.html. 
the audit market, as defined by client-firm size (GAO (2008) $)^{17}$. In the large company market segment, the Big $4 \mathrm{~s}$ ' relative dominance can be linked to several factors. First, smaller auditors generally lack the capacity and expertise to audit large public companies given the size and complexity of their operations. Second, the lack of a significant international network can also limit smaller auditors' ability to effectively and efficiently audit larger multinational companies. Third, larger companies may preferably seek a Big 4 auditor as the benefit they derive from a Big 4 audit (and other non-audit services) can be proportionally greater than for small to medium sized companies. For the most part, these factors are specific to large public companies and auditors must develop adequate audit expertise and capability before entering this segment of the market. As a result, the market for large company audits is almost exclusively exogenously restricted to the larger Big 4 auditors.

Because this study seeks to understand and identify differences in Big-4 and non-Big 4 audit firms' production processes which result endogenously from diverging investments strategies rather than exogenous clientele effects, we consider the large company and the small to medium sized company segments as distinct audit markets. Hence, we restrict our analysis to the small to medium sized public company segment with no significant international operations where both groups of auditors are actively present. Specifically, we only retain client-firm-year observations with total assets below $\$ 500$ million and exclude client-firm-year observations where the number of reported geographical segment is above one. In this setting, auditor choice is not naturally limited to large auditors because of high exogenous entry costs or other constraints. The objective here is to provide a more powerful setting for our tests ${ }^{18}$.

\footnotetext{
${ }^{17}$ For example, the Big-4 audit firms audited $98 \%$ of public companies with annual revenues above $\$ 1$ billion and the Hirschman-Herfindahl Index (HHI) for this market segment was about 0.25 in 2006. Yet, the HHI for the audit market for small public companies with annual revenues of less than $\$ 100$ million fell to about 0.08 and just below 0.18 for public companies with annual revenues between $\$ 100$ million and \$500 million (GAO (2008)).

${ }^{18}$ Segmenting audit markets on the bases of client-firm size is common in the literature (e.g., Simunic (1980); Francis and Stokes (1986); Palmrose (1986)). Empirical analyses in government sponsored studies of the audit industry are often performed on some bases of company size (see GAO $(2003,2008)$; Oxera Consulting (2006, 2007); London Economics (2006)). We also note that price competition likely plays a more significant role in the small to medium sized public company market segment which in turn would
} 
In the same vein, we compare Big 4 to non-Big 4 audit fees in part to control for nonobservable input costs differences potentially correlated with market size (e.g., labour). That is, non-Big 4 audits are used as a control group for (exogenous) market specific costs differences correlated with market size. Observations within any restricted group are likely more comparable and thus allow for a better control for these differences. Moreover, our restricted sample results in roughly the same number of Big 4 and non-Big 4 audits.

Finally, production costs differences between Big 4 and non-Big 4 auditors are inferred from audit fees charged in relation to local market characteristics, namely market size. As such, there is an implicit assumption that the local audit engagement office manages and performs the majority of the audit engagement. This is important because local geographical market characteristics are associated with the location of the local engagement office. If multiple offices are involved in an engagement, different markets are involved and it becomes difficult to associate audit fees to characteristics of one specific market (i.e., non-independent local markets). Audits for small to medium companies with only one reported geographical segment are less likely to involve multiple offices and thus less subject to this concern.

\section{Audit Fee Model}

We extend the standard audit fee model to allow for differences in audit pricing as suggested in Sirois and Simunic (2010).

Audit fees are simply defined as total audit effort multiplied by an auditor's weighted average billing rate. Formally:

$$
A U D F E E_{j}=P_{j} \times E F F O R T_{j}
$$

allow for efficiency gains and economies of scale to more directly translate into lower audit fees in this market segment. 
where $P_{j}$ is auditor $j$ 's weighted average billing rate and $E F F O R T_{j}$ represents total audit hours.

To simplify, we assume, as is standard in the auditing literature, that: (1) individual audit firms $j$ are of one of two types, Big 4 and non-Big 4, and that auditors of a given type are essentially identical; and (2) the relative difference between Big 4 and non-Big 4 auditors in the total amount of audit effort is constant in engagement characteristics ${ }^{19}$. This makes it possible to isolate the effects of engagement characteristics and auditor type on audit effort purchased. Formally:

$$
\text { EFFORT }\left(\Phi_{i t}, T\right)=X\left(\Phi_{i t}\right) L A B O U R \quad(T)
$$

Where EFFORT is the total amount of audit effort purchased by client-firm $i$ in year $t$, with $\Phi_{i t}$ representing a vector of engagement specific characteristics and $T$ indicating auditor type ( $T=\operatorname{Big} 4$, non-Big 4). On the right hand side, $X\left(\Phi_{i t}\right)$ is the total amount of audit hours purchased conditional on engagement characteristics, and $L A B O U R(T)$ is a positive adjustment factor to audit effort to account for differences in audit production processes between Big 4 and non-Big 4 auditors. We also assume that auditor's billing rates are equal across auditors of the same type $\mathrm{e}^{20}$. Consequently, total audit fees paid by client-firm $i$ for its year $t$ audit is then equal to:

$$
\begin{aligned}
& \text { AUDFEE }\left(\Phi_{i t}, T=B 4\right)=P_{B 4}\left[X\left(\Phi_{i t}\right) L A B O U R{ }_{B 4}\right] \\
& \operatorname{AUDFEE} \quad\left(\Phi_{i t}, T=N B 4\right)=P_{N B}\left[X\left(\Phi_{i t}\right) L A B O U R{ }_{N B} 4\right]
\end{aligned}
$$

That is, total audit fee is equal to total effort multiplied by the auditor's average hourly billing rate $P_{T}$, with $T$ indicating Big 4 or non-Big 4 . In equilibrium, auditors will set their prices in proportion to their marginal cost such that billing rates are a function of auditor

\footnotetext{
${ }^{19}$ Basically, in a standard audit fee model, this difference between Big 4 and non-Big 4 auditors is captured as a component of the Big 4 audit fee premium in a Big 4 indicator variable.

${ }^{20}$ Billing rates can also vary across years and client-firm characteristics (e.g., legal risk). However, any such variations, given the multiplicative nature of the model, are essentially captured by year indicator variables and engagement specific controls, $X\left(\Phi_{i t}\right)$.
} 
type and marginal costs (Sirois and Simunic (2010)). On the one hand, as is generally accepted in the literature, Big 4 auditors are characterised as an oligopoly (e.g., GAO (2003, 2008); Sirois and Simunic (2010)) such that they can potentially price their services above marginal cost. When modeling Big 4 audit firm competition as a Cournot oligopoly, $P_{B 4}$ is a function of Big 4s' marginal cost and the number of Big 4 auditors operating in a given local market in a given year (i.e., entrants). Moreover, given our hypothesis that audit technology investments "locally" made by Big 4 audit firms (in relation to market size) involve predominantly process innovation, Big 4s' marginal costs are decreasing in the level of such investments, identified by $\zeta$.

On the other hand, since the non-Big 4 market segment is highly fragmented with virtually no product differentiation among auditors, it is generally accepted that non-Big 4 auditors operate in an almost perfectly competitive market segment such that they will price their audits at marginal cost. Hence, auditors' billing rates are equal to (see Sirois and Simunic (2010) (eqs. (6) and (9) $)^{21}$ :

$$
\begin{aligned}
P_{B 4} & =\left(\frac{N_{B 4}}{N_{B 4}-1}\right) \frac{C_{B 4}}{\zeta_{B 4}} \\
P_{N B 4} & =C_{N B 4}
\end{aligned}
$$

where $N_{B 4}$ is the number of entrants (i.e., Big 4 audit firms operating in a local market for a given year) ${ }^{22}, C_{T}$ is equal to marginal (hourly) costs, with $T=\operatorname{Big} 4$, non-Big 4 , and $\zeta$ measures the level of process innovation technology investments made by a Big 4 local office. Because audit technology is fixed at the time of production, marginal cost is equal to the unit cost of audit effort. The cost of audit effort is allowed to vary between auditor types to reflect differences in audit production processes ${ }^{23}$. Notice here that legal and

\footnotetext{
${ }^{21}$ Here, eq. (6) is modified to allow for the possibility of process innovation captured by $\zeta$ (see Sutton (1998); Ellickson (2004); Sirois and Simunic (2010)).

${ }^{22} N_{B 4}$ is a measure of Big 4 market power and is a decreasing function of the number of Big 4 entrants, albeit, at a decreasing rate.

${ }^{23}$ Notice as well that an "additional mark-up" on marginal cost is possible so long as the ratio of (real and/or perceived) audit quality enhancing technology $\left(\delta_{j}\right.$ in Sirois and Simunic (2010)) over price $p_{j}$ remains sufficiently high relative to other auditors to guaranty that the auditor controls sufficient market
} 
reputational costs are excluded from the model to simplify the analysis. In any case, these costs are assumed constant per audit firm type and borne at the national level, when controlling for engagement specific characteristics ${ }^{24}$.

Marginal input factor costs for both Big 4 and non-Big 4 auditors are likely positively correlated with market size. For example, auditor salaries are likely higher in larger markets such as Chicago and New York where the cost of living is higher. Because we are merely interested in controlling the portion of input factor costs correlated with market size, we directly use market size as a proxy for marginal costs. Formally:

$$
C_{T}=M I X_{T} f(M K T S I Z E)
$$

where $M I X_{T}$ is a positive "weighting" factor; $M I X_{T}>1$ indicates that the audit firm's weighted average marginal cost is above the local market average input factor cost. This weighting factor is appropriately allowed to vary according to auditor type, although it remains constant across markets (again, given engagement characteristics). Marginal input factor costs are assumed increasing in market size: $f^{\prime}(\cdot)>0$. Because $\zeta$ is also an increasing function of market size, we proxy for investments in process innovation using market size: $g($ MKTSIZE $)$, where $g^{\prime}(\cdot)>0$.

Therefore, total audit fees paid by client-firm $i$ for its year $t$ audit is equal to:

shares to recover its investments in audit technology. In equilibrium, however, all auditors of the same type employ the same strategy so that this ratio is equal across auditors of the same type and set to the minimum value of $\left(N_{\mathrm{B} 4} /\left(N_{\mathrm{B} 4}-1\right)\right)$. Moreover, even if such a mark-up exists it would apply at the national partnership level and not expected to be correlated in any particular way with local market size.

${ }^{24}$ Future legal and reputational costs associated with audit failure are a function of client-firm specific risk and are captured by $\mathrm{X}\left(\Phi_{i t}\right)$ in eq. (2). Yet, because legal and reputational costs may proportionally differ between Big 4 and non-Big 4 auditors (e.g., DeAngelo (1981); Dye (1993); Lennox (1999)), such costs would also be captured by an auditor type indicator variable (i.e., Big 4 "dummy") in a standard regression model (including the "LABOUR ${ }_{B 4}$ " parameter in eq. (3a)). However, legal environment is constant across all local U.S. markets and reputational costs are associated to an auditor's band name, which, for any give auditor, is also constant across all local U.S. markets. Hence, legal and reputational costs differences between Big 4 and non-Big 4 auditors will be constant across all local markets and therefore not affect the results (i.e., unrelated to local market size). 


$$
\begin{aligned}
& \operatorname{AUDFEE}_{i t}(T=B 4)=\left(\frac{N_{B 4}}{N_{B 4}-1}\right)\left[\operatorname{MIX}_{B 4} \frac{f(\text { MKTSIZE })}{g(\text { MKTSIZE })}\right]\left[X\left(\Phi_{i t}\right) \operatorname{LABOUR}_{B 4}\right](6 \mathrm{a})
\end{aligned}
$$

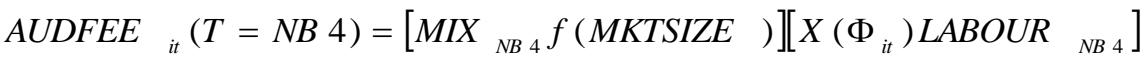

Because $M I X_{T}$ and $L A B O U R_{T}$ are essentially indicator variables, we group them together, and take the natural log to obtain:

$$
\begin{aligned}
& \text { LNFEE }_{i t}(T=B 4)= \\
& \ln \left(\text { MIX }_{B 4} \text { LABOUR }_{B 4}\right)+\ln \left(\frac{N_{B 4}}{N_{B 4}-1}\right)+\ln \left(f\left(\text { MKTSIZE }_{B}\right)\right)-\ln (g(\text { MKTSIZE }))+\ln \left(X\left(\Phi_{i t}\right)\right)
\end{aligned}
$$

$$
\begin{aligned}
& \operatorname{LNFEE}_{i t}(T=N B 4)=
\end{aligned}
$$

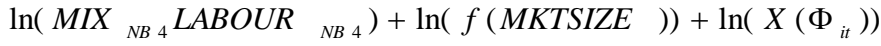

Eqs. (7a) and (7b) show clearly how the standard audit fee model should be adapted for testing our hypothesis. $X\left(\Phi_{i t}\right)$ captures well known engagement specific fee determinants included in standard audit fee models. These are explored in greater detail below. Other terms, namely $N_{B 4}$ and MKTSIZE, are observable market specific factors which the theory suggests should be included (notice that $N_{B 4}$ is also year specific). Because market size appears in two different components of Big 4 audit fees, we take advantage of the presence of non-Big 4 audits to estimate $g(\cdot)$. Essentially, we jointly estimate eqs. (7a) and (7b) to explicitly control for local market input factor cost differences (i.e., non-Big 4 audits serve as a control group). Formally:

$$
\begin{aligned}
& \text { LNFEE }_{i t j}=\alpha_{0}+\alpha_{1} B I G 4_{i j j}+\beta_{1} L_{N G D P} \\
& +\beta_{2}\left(B I G 4_{i t j} * L N G D P_{j}\right)+\beta_{3}\left(B I G 4_{i j j} * L N B I G 4_{i j}\right) \\
& +\phi_{1} \text { LNTA }_{i j j}+\phi_{2} \text { INVREC }_{i j j}+\phi_{3} \text { LOSS }_{i j j}+\phi_{4} R_{i j} \\
& +\phi_{5} L E V_{i j j}+\phi_{6} N B S_{i j j}+\phi_{7} N A S_{i j}+\phi_{8} \text { CONCERN } i i j \\
& +\phi_{9} N E W A U D_{i j}+\phi_{10} B U S Y_{i j}+(\text { fixed effects })+\varepsilon_{i j j}
\end{aligned}
$$


Where for local market $j$ :

$$
\begin{aligned}
& L N F E E_{i j t}=\text { natural } \log \text { of audit fee }(\$ \mathrm{k}) \text { of client-firm } i \text { in year } t \\
& B I G 4_{i t j}=1 \text { if client-firm } i \text { is audited by a Big } 4 \text { auditor in year } t, 0 \\
& \text { otherwise; } \\
& L N G D P_{j}=\text { natural log of local market } j \text { size, defined as the average }
\end{aligned}
$$

\footnotetext{
25 Source: http://www.bea.gov/regional/gdpmetro/. The Bureau reports annual GDP figures. We use constant 2001 dollars to limit the effect of inflation. Furthermore, we take the average of MSA GDP over a five year period (the study spans from 2002 to 2005) to limit noise as there is arguably a lag between changes in local market size and audit firms' investments decisions.
} 


$$
\begin{aligned}
N E W A U D_{i t j}= & \begin{array}{l}
1 \text { if a different auditor from year } t-1 \text { audited client-firm } i \text { in year } \\
t, 0 \text { otherwise; }
\end{array} \\
B U S Y_{i j j}= & \begin{array}{l}
1 \text { if firm } j \text { 's fiscal year end } t \text { is in December or January, } 0 \\
\text { otherwise; }
\end{array}
\end{aligned}
$$

Fixed effects $=$ year and industry (2-digit SIC) fixed effects.

Consistent with eq. (7a), we predict the coefficient on $L N G D P$ to be positive: $\beta_{1}>0$, while the coefficient on $B I G 4^{*} L N G D P$ is expected to be negative: $\beta_{2}<0$. Indeed, a negative coefficient would be consistent with our hypothesis that Big 4 firms benefit from economies of scale which result in decreasing Big 4 fee premium with market size. MSA GDP captures the size of a local economy and therefore presents a fair estimate of local commercial opportunities available to auditors ${ }^{26}$. It is those investment opportunities that drive the technological investments which create the potential for economies of scale ${ }^{27}$. The coefficient on BIG4 essentially captures differences between Big 4 and non-Big 4 auditor MIX and LABOUR as defined above and is expected to be positive $^{28}$.

$B I G 4 * L N B I G 4$ is a proxy for Big 4 market power ${ }^{29}$. As per eq. (4a), Big 4 auditor billing rate is decreasing in $N_{B 4}$. Accordingly, we predict the coefficient on $B I G 4 * L N B I G 4$ to be positive: $\beta_{3}>0$. Notice that, as the theory suggests, the number of Big 4 and non-Big 4 entrants does not affect non-Big 4 audit firms' pricing strategy.

\footnotetext{
${ }^{26}$ Penno and Walther (1996)) use population as a measure of local market size. However, GDP is more appropriate for this study since company financial audits are "business", rather than "consumer" products. In any case, population is almost perfectly correlated to GDP with Pearson correlation coefficients of 0.991 .

${ }^{27}$ The number of audits and total market audit fees in a given market would be a misleading measure as private and large public companies are excluded from the sample. More important still, using audit fees as a measure of audit market size would be problematic as this measure would be endogenous to our dependent variable. Furthermore, some audit clients, albeit a few, come from a different MSA as their auditor. In any case, GDP is highly correlated to the number of audits and total market audit fees with Pearson correlation coefficients of 0.88 and 0.86 respectively.

${ }^{28}$ As stated above, this coefficient may also capture any other form of premium and/or "adjustment" to Big 4 audit fees relative to non-Big 4 audit fees (such as an "insurance" premium). However, controlling for engagement specific characteristics these adjustments are expected to remain constant across markets.

${ }^{29}$ We also use $\log \left(N_{B 4}\right)$ as an alternative control for Big 4 market power. Results from all tests using this control are equivalent to results using $L N B I G 4$ as defined previously, except that the sign on $\log \left(N_{B 4}\right)$ is, as expected, negative.
} 
Other independent variables included in eq. (8) are commonly used control variables (see Hay, Knechel, and Wong (2006) for a meta-analysis). These variables stand for $X\left(\Phi_{i t}\right)$ in eqs. (3a) and (3b). We include LNTA to control for client-firm size; INVREC to control for inherent risk; LOSS, ROA, and $L E V$ to control for client-specific litigation risks to be borne by the auditor; and $N B S$ to control for client-firm complexity. As is well documented in the literature, audit fees are positively associated to client-firm size, inherent risk, client-firm-specific risk factors and complexity. Therefore, we predict all coefficients on these engagement specific control variables to be positive, except for the coefficient on $R O A$ which is expected to be negative (i.e., $\phi_{1}, \phi_{2}, \phi_{3}, \phi_{5}, \phi_{6}>0, \phi_{4}<0$ ).

We use NAS to control for the possible impact on audit fees of the joint provision of nonaudit services (NAS). The provision of NAS can lead to lower audit fees as a result of the cross-subsidization of audit fees or synergies between audit and non-audit services. Alternatively, NAS may be associated with organizational problems or operational changes in the client-firm which can lead to higher audit fees. Accordingly, we offer no prediction for the sign of the coefficient on NAS (i.e., $\phi_{7}=$ ?). We also offer no prediction for the sign of the coefficient on NEWAUD (i.e., $\phi_{8}=$ ?) since it is unclear whether a change of auditor will lead to lower or higher audit fees, all else equal. For example, a new auditor may offer a discount to gain new clients (i.e., "low-balling"). In contrast, a new auditor may face significant start-up costs and charge higher audit fees as a result.

We predict both coefficients on CONCERN and BUSY to be positive (i.e., $\phi_{9}, \phi_{10}>0$ ). We use CONCERN to control for audit problems related to the engagement that are expected to be positively correlated with audit fees. BUSY represents the "busy-season" during which most client-firms have their fiscal year-end. Consequently, audit fees are expected to be higher during this period because audit firms may engage additional expenses (e.g., staff overtime) or because they may offer discounts at other periods when staff resources are less occupied. Finally, we include fixed effect dummies for industry (two-digit SIC codes) and years to control for potential variations in audit fees across industries and over time. 
As an additional test, we augment eq. (8) to explicitly control for labour specific input costs. This allows us to obtain a better understanding of audit production function differences between Big 4 and non-Big 4 auditors and explore possible sources of efficiency gains and economies of scale realised by Big 4 local audit offices. Indeed, labour is undeniably the most important factor of production in the audit process. Moreover, labour input costs are highly positively correlated with market $\operatorname{size}^{30}$. We nonetheless retain MKTSIZE (i.e., $L N G D P$ ) as a control variable to proxy for factor input costs correlated with market size, but not labour costs. Formally, this changes eq. (5) to:

$$
C_{T}=M_{T}{ }_{T} f_{T}(S A L A R Y, M K T S I Z E)
$$

where $S A L A R Y$ corresponds to the (hourly) wage level on the labour market for auditors. We also allow Big 4 and non-Big 4 auditors to possess different costs functions; that is, the use of production inputs varies between auditor types. Incorporating eq. (9) into our model leads to the following regression model:

$$
\begin{aligned}
& \text { LNFEE }_{i j}=\alpha_{0}+\alpha_{1} B I G 4_{i j}+\beta_{1} L_{N G D P_{j}} \\
& +\beta_{2}\left(B I G 4_{i t j} * L N G D P_{j}\right)+\beta_{3}\left(B I G 4_{i j j} * L N B I G 4_{i j}\right) \\
& +\beta_{4}\left(\operatorname{LNSAL}_{i j}\right)+\beta_{5}\left(B I G 4_{i t j} * L N S A L_{t j}\right) \\
& +\phi_{1} \text { LNTA }_{i j j}+\phi_{2} \text { INVREC }_{i i j}+\phi_{3} L_{i j}+\phi_{4} R O A_{i j j} \\
& +\phi_{5} L E V_{i j j}+\phi_{6} N B S_{i j j}+\phi_{7} N A S_{i j j}+\phi_{8} C O N C E R N i i j \\
& +\phi_{9} N E W A U D_{i j j}+\phi_{10} B U S Y_{i j}+(\text { fixed effects })+\varepsilon_{i j}
\end{aligned}
$$

where $L N S A L$ is equal to the MSA specific median hourly wage for "Accountants and Auditors" (SOC code 132001) as reported for May of each sample year (year and market specific) by the Bureau of Labor Statistics (U.S. Department of Labor) ${ }^{31}$. We predict the coefficient on $L N S A L$ to be positive: $\beta_{4}>0$. We predict the coefficient on $B I G 4 * L N S A L$,

\footnotetext{
${ }^{30}$ We use a market and year specific measure for the level of labour costs which also allows to control more directly for the effect of inflation. Note that engagement specific controls are also expressed in nominal terms and control partially for inflation as well. Any remaining impact of inflation is captured by year fixed effects.

${ }^{31}$ Source: Occupational Employment Statistics, http://data.bls.gov/oes/search.jsp.
} 
to be positive: $\beta_{5}>0$, which would indicate that Big 4 firms benefit from greater returns from labour input than non-Big 4 auditors. That is, for a given increase of labour input cost, Big 4 auditors are "capable" of increasing output (i.e., higher fees). As we discuss in the next section, because labour costs are positively correlated with market size, $\beta_{5}$ is a measure of returns to scale. In fact, if $\beta_{4}+\beta_{5}>1$ it can be said that Big 4 auditors benefit from increasing returns to scale.

To formally test our hypothesis, we estimate eqs. (8) and (10) using OLS and assess if the coefficient on $B I G 4^{*} L N G D P$ is significantly smaller negative: $\beta_{3}<0$.

\section{SAMPLE AND RESULTS}

\section{Sample}

Audit fee and auditor information are obtained from Audit Analytics. The initial sample consists of all observations for fiscal years 2002 to 2005 with available audit fee and auditor information (i.e., name and location of the engagement office) ${ }^{32,33}$. We restrict our sample to metropolitan areas to exclude very small markets with population below 50,000. Furthermore, we impose a minimum of three observations per market-year. This requirement is to ensure that a minimum of audit activity occurs in a given market, for a given year, and that there is sufficient data to draw reliable inferences about market structure (i.e., number of Big-4 entrants) and audit firm conduct (i.e., audit fees).

Client-firm financial statement information, industry membership and geographical segment data is obtained from Compustat; the number of geographical segments is assumed to be equal to one when no information is available. As discussed above, financial institutions (SIC 6000-6999), along with firm-year observations with total assets above $\$ 500$ million or with more than one reported geographical segment are excluded. Observations with total assets equal to $\$ 0$ (or missing) or with missing industry

\footnotetext{
${ }^{32}$ Fiscal year is as defined by Compustat. We choose 2002 as the starting year to retain only audits performed post-Enron.

${ }^{33}$ A future version of this paper will include data up to financial year 2009.
} 
information are excluded ${ }^{34}$. Furthermore, we exclude client-firms with two or more auditors identified for a given year (identified as "joint audits"). We also exclude observations for which it is impossible to identify if an auditor change has occurred ${ }^{35}$. The test sample consists of 7,416 observations from 83 different U.S. local markets (301 market-years), split equally between Big-4 and Non-Big-4 audits (Table 1).

\section{INSERT TABLE 1 HERE.}

Table 1 presents the descriptive statistics, where audit engagements are grouped by auditor type and market size category, pooled across all years. Engagement specific control variables are generally constant across all market size categories. This is supported by the pair-wise correlations reported in Table 2. Pair-wise correlations between $L N G D P$ and engagement specific control variables are all 0.06 and -0.048 (except BIG4 which is still relatively low at -0.139). As expected, however, market specific control variables $L N S A L$ and LNBIG4 are correlated with market size. The correlation between $L N S A L$ and $L N G D P$ is especially high (0.63). Audit fees appear to increase somewhat in market size, most probably driven by LNSAL (i.e., the local price of labour). This suggests that eq. (10) is susceptible to multicollinearity.

Noteworthy are the differences between client-firms audited by Big 4 auditors and those audited by non-Big 4 auditors. The data confirms that Big 4 auditors audit larger and more complex client-firms ( $L N T A$ and $N B S$ ). They also audit relatively more profitable and less risky client-firms that report net losses less often (LOSS), have larger return-onassets $(R O A)$ and are less leveraged ( $L E V$ ). Not surprisingly, non-Big 4 auditors issue more going concern opinions on average than Big 4 auditors (CONCERN: $42 \%$ vs. 8\%) as a result. Big 4 auditors also provide relatively more NAS to their clients $(N A S)$ and audit more client-firms with December-January year-end (BUSY). NEWAUD for non-Big

\footnotetext{
${ }^{34}$ When possible, this information is obtained from Audit Analytics when it is not available from Compustat. If the SIC code is not available, financial institutions are identified from their NAICS code when reported.

${ }^{35}$ This is to accurately derive the NEWAUD control variable Specifically, client-firms-year observations for which the first year of available auditor information in the Audit Analytics database falls between 2002 and 2005.
} 
4 auditors is over three times higher than for Big 4 auditors. This coincides with the increase number of auditor switches by small and medium companies from a Big 4 audit firm to a smaller-tier auditor following the passage of $\mathrm{SOX}^{36}$.

As expected, Big 4 audit fees are higher than non-Big 4 audit fees. However, pair-wise correlations between engagement specific control variables and audit fees (LNFEE) are often significant, confirming that audit fees are driven by client-firm characteristics (Table 2). Finally, pair-wise correlations between control variables are generally low and suggest that multicollinearity is not a serious problem.

\section{INSERT TABLE 2 HERE.}

\section{Results}

We report in columns (1) and (2) of Table 3 the OLS estimates of regression coefficients of eq. (8) and (10) respectively, along with $t$-statistics in parentheses ${ }^{37}$, using the full sample of client-firms pooled over years and markets. Column (3) presents the results of a robustness test and are discussed later.

\section{INSERT TABLE 3 HERE.}

First, the coefficient estimate on $B I G 4^{*} L N G D P$ is significantly negative, albeit at the $10 \%$ level, in the base model (eq. (8), column (1)). The coefficient from eq. (10) (column (2)) is also significantly negative (at the $0.1 \%$ level or better). Overall, the evidence is consistent with our hypothesis and indicates that Big-4 audit fee premium is, ceteris paribus, decreasing in market size.

Second, the coefficient estimates on $L N G D P$ is, as expected, positive (and highly significant), confirming the importance to control for factor input costs differences across markets. In fact, when we include specific controls for labour costs (column (2)), the

\footnotetext{
${ }^{36}$ Big-4 auditors also tend to have longer tenure.

${ }^{37} t$-statistics are based on heteroskedasticity-consistent standard errors which are robust to within clientfirm correlation (i.e., clustered SE).
} 
result on $B I G 4 * L N G D P$ remain negative and even more significant. However, the coefficient on LNSAL (column (2)) is negative and opposite from its expected sign, although not significantly different from 0 at conventional levels. One possible concern is that because $L N G D P$ and $L N S A L$ are so highly correlated it may be difficult to estimate the coefficients with accuracy (i.e., multicollinearity).

Third, the coefficient on $B I G 4 * L N S A L$ is, as expected, significantly positive. Because LNSAL is highly positively correlated with market size (and thus investment opportunities), the sum of $\beta_{4}+\beta_{5}=1.297>0$ is an indication of increasing returns to scale for Big 4 auditors. Indeed, for an increase in local auditor salary of 1\%, Big 4 firms are successful in increasing "output" by $1.297 \%$. Increasing returns likely occur for two reasons: (1) Big 4 audit quality may be increasing in market size $\mathrm{e}^{38}$; and/or (2) increasing productivity in market size ${ }^{39}$. The first scenario is consistent with evidence reported by Francis and $\mathrm{Yu}$ (2009) who find that audit quality is increasing in office size for a sample consisting of only Big 4 audits. Moreover, Choi et al. (2010) also report increasing audit quality with office size, although they do not restrict their analysis to Big 4 audits. Both groups of authors use standard measures and measure office size by total office level audit fees. Hence, because office size is highly correlated with market size, and even more so with Big 4 offices ${ }^{40}$, both results would suggests that Big 4 audit quality is increasing in market size and, if anything, would suggest that Big 4 fee premium should be increasing in market size ${ }^{41}$.

Alternatively, the second scenario of increasing productivity would suggest that Big 4 audit premium should be decreasing in market size. Here, a positive coefficient on

\footnotetext{
${ }^{38}$ This is equivalent to an increase in audit output since an audit is defined along quality attributes and clients will pay for higher audit quality. However, small to medium sized companies are less likely to benefit from higher audit quality which would limit the extent to which Big 4 audit firms seek to invest in audit quality for this market segment.

${ }^{39}$ To illustrate, one can think of the reciprocal of $\beta_{4}+\beta_{5}$ : an increase in $1 \%$ of Big 4 audit fees involves an increase of $1 / 1.297=0.787 \%$ in labour costs.

${ }^{40}$ Unreported market structure data suggests that Big 4 office size is highly correlated with market size, while non-Big 4 office size remains mostly constant across markets. This is in fact entirely consistent with Sirois and Simunic (2010).

${ }^{41}$ Notice here, however, that the fee premium is linked to "improvements" in human capital (i.e., positive coefficient on $\left.B I G 4^{*} L N S A L\right)$.
} 
$B I G 4 * L N S A L$ is equivalent to decreasing average labour costs for Big 4 auditors, part of which can result from Big 4 firms' ability to more appropriately manage capacity slack in larger offices ${ }^{42}$. In a more general sense, a positive coefficient is consistent with an increasing proportion of labour costs as a percentage of average engagement hour costs and is entirely in line with the idea that Big 4 auditors benefit for economies of scale ${ }^{43}$.

We note however that both scenarios are simultaneously possible. That is, Big-4 audit quality may be increasing in market size resulting in an increase in fees; however, efficiency gains simultaneously allow Big 4 auditors to "compensate" their clients and lower their fees. The fact that $B I G 4 * L N G D P$ is negative in both eqs. (8) and (10) suggests that the latter effect dominates. Overall, although we believe that Big 4 audit quality remains mostly constant across U.S. local markets, the possibility that it may be increasing, as suggested Francis and Yu (2009) and Choi et al. (2010), strongly biases against our hypothesis, making our results all the more noteworthy. Moreover, the end result remains the same in that the ratio of audit quality over audit fees for Big 4 audits relative to non-Big 4 audits is increasing in market size. That is, Big 4 audit value is increasing in market size as argued by Sirois and Simunic (2010). Ultimately, the value of Big 4 audits in our sample is increasing mostly as a result of a reduction in Big 4 audit fees relative to non-Big 4 auditors.

In fact, Choi et al. (2010) find evidence that audit fees are increasing in office size. We believe that their test viable (i.e., office size rank across all years) captures similar effects as our test variable $(B I G 4 * L N G D P)$ which suggests that our two studies report conflicting results $^{44}$. Yet, our research designs differ and may not be entirely comparable;

\footnotetext{
42 Average hour labour cost for an audit firm is actually equal to local auditor salary (on an hour basis) divided by the percentage of productive (i.e., billable hours) out of the total number of hours worked (or on which annual salary is converted to an hour basis). Hence, as the percentage of billable hours increases, average labour costs decreases.

${ }^{43}$ In other words, as "office overhead" costs are spread over more engagements, the proportion of marginal labour costs becomes more important relative to total average costs (i.e., labour becomes an increasing proportion of engagement costs and thus fees). This is more likely for audit firms where office level technology costs are important and when office size is increasing in market size, which is almost exclusively the case for Big 4 offices.

${ }^{44}$ As stated before, office size is highly correlated with market size, and even more so with Big 4 office size. In other words, the largest offices in their sample would be Big 4 offices operating in the largest
} 
we also raise several concerns with their research design. First, our study focuses on the small to medium company market segment which we believe offers a stronger research setting, for reasons explained above. Second, one of their test variables (i.e., OFSIZE2) is based on audit fees and thus not entirely independent from the dependent variable, audit fees $^{45}$. Third, the authors do not explicitly control for time specific effects in their regression model which potentially biases (significantly) in favour of their results. Indeed, as a result of major shocks in the audit market (e.g., SOX), audit fees have increased significantly over the six year period of their study, from 2000 to 2005 (Rummell (2007)). This is problematic since their measure of office size is equal to office-year specific audit fees divided by the largest value of total office annual fees estimated from the full sample pooled across all years. As a result, both their dependent and test variables are highly correlated with uncontrolled time effects. In other words, the largest values of office size, as per their measure, disproportionally correspond to officeyears in the latest years of their sample, where audit fees are most likely inflated as a result of SOX and other market shocks ${ }^{46}$. Finally, the authors perform several robustness tests to control for the possible positive correlation between office size and local input costs which can bias in favour of their results. Nonetheless, we feel the structured approach we propose to explicitly control for input costs differences across local markets offers a stronger control.

Turning now to the last market (and year) specific control variable, we note that the coefficient on $B I G 4 * L N B I G 4$ is of the expected sign, but overall small and not significantly different from 0 in all cases. Overall, the evidence does not suggest that Big 4 auditors extract significant monopoly rents, at least in the small to medium sized company market segment, and price competition among the Big 4 audit firms appears

markets. From this perspective, we believe it would have been more appropriate for their research design to control for Big 4 and non-Big 4 specific effects on office size, as auditor group membership and office size are not independent.

${ }^{45}$ Although they exclude for their measure of office size for each firm-year observations the specific audit fees for a client in a given year, the level of audit fees at the office level and the specific engagement level are nonetheless likely driven by common factors not controlled for by engagement specific control variables. This potentially results in correlated omitted variable bias.

${ }^{46}$ This effect in only heightened by the fact that larger offices and higher fees are more likely in larger markets partially because of higher input costs for which they only control for in robustness tests. 
strong. This is formal proof supporting conclusions made by the GAO $(2003,2008)$ that the high level of concentration in the auditing industry, dominated by the Big 4, does not seem to have had an adverse effect on audit fees thus far. The Big 4 audit fee premium, relative to non-Big 4 auditors, appears in large part driven by difference in the audit production process and quality differential (i.e., vertically differentiated audits), rather than abusive market power by the Big 4 audit firms ${ }^{47}$.

Finally, coefficient estimates on all engagement specific control variables in both columns are all highly significant (at the $1 \%$ level or less, except $N E W A U D$ which is significant at the $10 \%$ level in column (2)), of the expected signs when predicted and similar in magnitude (Table 3, Section B). Specifically, audit fees have a statistically significant positive relation to client-firm size ( $L N T A)$; inherent (INVREC) and litigation risks ( $L O S S$ and $L E V$ ); and complexity (NBS and CONCERN). As expected, the coefficient on $B U S Y$ is also significantly positive. The coefficient on $R O A$ is significantly negative, consistent with the idea that client-firms with weak returns are riskier. The coefficient on $N A S$ is significantly negative which suggest the existence of synergies or economies of scope when auditors perform non-audit services and other management advisory services. The negative coefficient on NEWAUD suggests that auditors may be offering discounts (i.e., "low-balling") to attract new clients ${ }^{48}$.

\section{Robustness Tests}

To mitigate the possible multicollinearity problem associated with eq. (10), we reestimate eq. (10) without $L N S A L$ but by deflating audit fees by the market-year specific median hourly wage for "Accountants and Auditors" (i.e., LNFEES - LNSAL). This effectively imposes a coefficient of 1 on $\beta_{4}$ and allows us to estimate eq. (10) without

\footnotetext{
${ }^{47}$ In fact, when price competition is more intense, Bertrand oligopoly is more appropriate to model firm competition. Our hypothesis is nonetheless robust to Bertrand oligopoly (Sutton (1991)). When price completion is more intense, firm prices are closer to marginal costs which reduces the magnitude of the market power premium; $N_{B 4} /\left(N_{B 4}-1\right)$ converges to 0 as price competition increases.

${ }^{48}$ Two other phenomena may also be occurring at the same time. First, new auditors may simply be "poor" at estimating audit fees for new clients such that they price "accidentally" below production costs on first engagements. These auditors would adjust their pricing in future years (note: auditors that price "accidentally" above production costs would tend not to be selected by prospective clients). Second, the majority of auditor switches in the sample are from Big-4 auditors to Non-Big-4 auditors. Because NonBig-4 audit fees are lower, the NEWAUD variable may be capturing some of this fee differential.
} 
LNSAL. Moreover, we impose on the audit fee model what is arguably the theoretical value of $\beta_{4}$ (i.e., non-Big 4 audit firms experience constant returns to scale). In fact, when we regress eq. (10) without $L N G D P$ and $B I G 4 * L N G D P$ the coefficient on $L N S A L$ is equal to 0.966 ( $p$-value < 0.001$)$ and thus very close to 1 . Results from this robust model are consistent with results from eqs. (8) and (10). The coefficient on $B I G 4 * L N G D P$ is still significantly negative (and closer to results from eq. (8)). Interestingly, the sum of 1 plus the coefficient on $B I G 4 * L N S A L$ is equal to 1.421 , very close to $\beta_{4}+\beta_{5}=1.297$ from eq. (10) (column (2)).

As an alternative test, we also estimate eq. (10) and "modified" eq. (10) without $L N G D P$, $B I G 4 * L N G D P$ and $B I G 4$ (and no general intercept), but including a market specific "intercept" along with market specific Big-4 interaction terms. This allows us to mitigate the multicollinearity while also controlling for "market specific" unobservable characteristics. We then regress the estimates for market specific Big-4 premia on LNGDP (using both WLS and OLS). Unreported results are consistent with the notion that Big-4 audit fee premium is decreasing in market size. Finally, unreported results for all models are robust to alternative estimation techniques and variable definitions. Overall, the evidence strongly supports our hypothesis.

\section{CONCLUSION}

In this paper, we have provided formal proof in support of Sirois and Simunic (2010) who argue that Big 4 and non-Big 4 audit firms fundamentally differ with respect to their investment strategies in audit technology. Our most significant contribution is to empirically evaluate the degree to which Big 4 auditors achieve economies of scale resulting from investments in audit technology at the local U.S. office level and, more importantly, determine how this affects audit pricing differences between Big 4 and nonBig 4 auditors. Our research design which focuses on a particular segment of the audit market in a single country allows us to hold constant audit quality differences between Big 4 and non-Big 4 audit firms. We believe this provides the strongest setting for testing for economies of scale. 
Consistent with our hypothesis, we find that, relative to non-Big 4 auditors, Big 4 auditors benefit from economies of scale at the local office level. In turn, this results in decreasing Big 4 audit fees in local market size, relative to non-Big 4 audit fees (i.e., decreasing Big 4 audit fee premium). Overall, our results also have important policy implications. Taken together, the results are consistent with the framework proposed by Sirois and Simunic (2010) and suggest that the U.S. audit industry remains price competitive, despite the high level of concentration. That is, Big 4 audit firms' domination of the industry does not seem to have adversely impacted audit fees. Surveying client-firms, auditors, academics and other market participants, the GAO reached similar conclusions in its most recent study of the industry (GAO (2008)). This study, however, offers more formal evidence on these issues. 


\section{REFERENCES}

Advisory Committee on the Auditing Profession. 2008. Final Report of the Advisory Committee on the Auditing Profession to the U.S. Department of the Treasury. Washington, D.C.: U.S. Department of the Treasury.

Audit and Assurance Faculty. 2005. Shareholder Involvement - Competition and Choice. In Audit Quality Forum. London, UK: The Institute of Chartered Accountants in England \& Wales.

Choi, J.-H., C. F. Kim, J.-B. Kim, and Y. Zang. 2010. Audit Office Size, Audit Quality, and Audit Pricing. Auditing: A Journal of Practice \& Theory 29 (1): 73-97.

Choi, J.-H., J.-B. Kim, X. Liu, and D. A. Simunic. 2008. Audit Pricing, Legal Liability Regimes, and Big 4 Premiums: Theory and Cross-Country Evidence. Contemporary Accounting Research 25 (1): 55-99.

Cole, M. 2008. Focus: The Fight over Audit Clients, Available online at http://www.financialweek.com/apps/pbcs.dll/article?AID=/20081116/REG/311179998, retrieved November 18, 2008.

Commission of the European Communities - Directorate General for Internal Market and Services. 2008. Commission Recommendation Concerning the Limitation of the Civil Liability of Statutory Auditors and Audit Firms. Brussels, Belgium: European Commission.

Danos, P., and J. W. Eichenseher. 1982. Audit Industry Dynamics: Factors Affecting Changes in Client-Industry Market Shares. Journal of Accounting Research 20 (2-Part II): 604-16.

Danos, P., and J. W. Eichenseher. 1986. Long-Term Trends toward Seller Concentration in the U.S. Audit Market. Accounting Review 61 (4): 633-50.

DeAngelo, L. E. 1981. Auditor Size and Audit Quality. Journal of Accounting and Economics 3 (3): 183-99.

Dye, R. A. 1993. Auditing Standards, Legal Liability, and Auditor Wealth. Journal of Political Economy 101 (5): 887-914. 
Eichenseher, J. W., and P. Danos. 1981. The Analysis of Industry-Specific Auditor Concentration: Towards an Explanatory Model. Accounting Review 56 (3): 479-92.

Ellickson, P. B. 2004. Supermarkets as a Natural Oligopoly. Working paper, Duke University. http://www.econ.duke.edu/ paule/research.html

Francis, J. R. 2004. What Do We Know About Audit Quality? The British Accounting Review 36 (4): 345-68.

Francis, J. R., and D. J. Stokes. 1986. Audit Prices, Product Differentiation, and Scale Economies: Further Evidence from Theaustralian Market. Journal of Accounting Research 24 (2): 383-93.

Francis, J. R., and M. D. Yu. 2009. Big 4 Office Size and Audit Quality. Accounting Review 84 (5): 1521-52.

Hay, D., and W. R. Knechel. 2009. The Effects of Advertising and Solicitation on Audit Fees. Journal of Accounting and Public Policy (forthcoming).

Hay, D., W. R. Knechel, and N. Wong. 2006. Audit Fees: A Meta-Analysis of the Effect of Supply and Demand Attributes. Contemporary Accounting Research 23 (1): 141-91.

Lennox, C. S. 1999. Audit Quality and Auditor Size: An Evaluation of Reputation and Deep Pockets Hypotheses. Journal of Business Finance \& Accounting 26 (7\&8): 779805.

London Economics. 2006. Study on the Economic Impact of Auditors' Liability Regimes. London, UK: Report Prepared for the European Commission: Directorate General for Internal Market and Services.

Oxera Consulting. 2006. Competition and Choice in the Uk Audit Market. Oxford, UK: Report Prepared for Department of Trade and Industry and Financial Reporting Council.

Oxera Consulting. 2007. Ownership Rules of Audit Firms and Their Consequences for Audit Market Concentration. Oxford, UK: Report Prepared for the European Commission: Directorate General for Internal Market and Services. 
Palmrose, Z.-V. 1986. Audit Fees and Auditor Size: Further Evidence. Journal of Accounting Research 24 (1): 97-110.

Penno, M., and B. R. Walther. 1996. The Concentration of Local Markets: A Study of Accounting, Advertising and Law. Accounting Horizons 10 (2): 88-99.

Rummell, N. 2008. Sarbox Caused Almost 350\% Increase in Audit Fees, Says Corporate Library Study, Available online at http://www.financialweek.com/apps/pbcs.dll/article?AID=/20070822/REG/70822008/10 36, retrieved October 22, 2008, 2008.

Simunic, D. A. 1980. The Pricing of Audit Services: Theory and Evidence. Journal of Accounting Research 18 (1): 161-90.

Sirois, L.-P., and D. A. Simunic. 2010. Auditor Size and Audit Quality Revisited: The Importance of Audit Technology. Working paper, HEC Montréal and University of British Columbia. Available at http://papers.ssrn.com/sol3/papers.cfm?abstract_id=1694613

Sutton, J. 1991. Sunk Costs and Market Structure: Price Competition, Advertising, and the Evolution of Concentration. Cambridge, MA: MIT Press.

Sutton, J. 1998. Technology and Market Structure: Theory and History. Cambridge, MA: MIT Press. Original edition, June 1998.

Taylor, M. H., and D. T. Simon. 1999. Determinants of Audit Fees: The Importance of Litigation, Disclosure, and Regulatory Burdens in Audit Engagements in 20 Countries. International Journal of Accounting 34 (3): 375-88.

The American Assembly. 2005. The Future of the Accounting Profession: Auditor Concentration. New York, NY.

U.S. Chamber of Commerce. 2006. Auditing: A Profession at Risk. Washington, D.C.

U.S. Chamber of Commerce. 2007. Commission on the Regulation of the U.S. Capital Markets in the 21st Century. Washington, D.C. 
United States General Accounting Office. 2003. Public Accounting Firms: Mandated Study on Consolidation and Competition. In Report. Washington, D.C.: Report to the Senate Committee on Banking, Housing, and Urban Affairs and the House Committee on Financial Services.

United States General Accounting Office. 2008. Public Accounting Firms: Continued Concentration in Audit Market for Large Public Companies Does Not Call for Immediate Action. In Report. Washington, D.C.: Report to Congressional Addressees.

Watkins, A. L., W. Hillison, and S. E. Morecroft. 2004. Audit Quality: A Synthesis of Theory and Empirical Evidence. Journal of Accounting Literature 23: 153-93. 
Table 1

Mean (Median) Audit Fee Sample Characteristics by Auditor Type and Market Size Category

\begin{tabular}{|c|c|c|c|c|c|c|c|c|c|c|c|c|c|}
\hline \multirow[b]{2}{*}{ Market GDP } & \multicolumn{6}{|c|}{ Big-4 } & \multicolumn{6}{|c|}{ Non-Big-4 } & \multirow{2}{*}{$\begin{array}{c}\text { Total } \\
\text { Sample }\end{array}$} \\
\hline & $\begin{array}{c}25 b \text { or } \\
\text { less }\end{array}$ & $\begin{array}{c}25 b- \\
50 b\end{array}$ & $\begin{array}{l}50 \mathrm{~b}- \\
100 \mathrm{~b}\end{array}$ & $\begin{array}{c}100 b- \\
300 b\end{array}$ & $300 b+{ }^{a}$ & $\begin{array}{c}\text { All } \\
\text { Markets }\end{array}$ & $\begin{array}{c}25 b \text { or } \\
\text { less }\end{array}$ & $\begin{array}{c}25 b- \\
50 b\end{array}$ & $\begin{array}{l}50 b- \\
100 b\end{array}$ & $\begin{array}{c}100 b- \\
300 b\end{array}$ & $300 b+{ }^{a}$ & $\begin{array}{c}\text { All } \\
\text { Markets }\end{array}$ & \\
\hline $\begin{array}{l}\text { Number of } \\
\text { Observations }\end{array}$ & 84 & 363 & 644 & 1958 & 703 & 3752 & 147 & 322 & 403 & 1530 & 1262 & 3664 & 7416 \\
\hline $\begin{array}{l}\text { Number of } \\
\text { market-years }\end{array}$ & 37 & 72 & 79 & 68 & 12 & 268 & 46 & 58 & 69 & 68 & 12 & 253 & 301 \\
\hline Number of markets & 13 & 19 & 20 & 17 & 3 & 72 & 18 & 17 & 19 & 17 & 3 & 74 & 83 \\
\hline Total Fees (\$k) & $\begin{array}{l}296.1 \\
(172)\end{array}$ & $\begin{array}{l}270.3 \\
(170)\end{array}$ & $\begin{array}{l}404.6 \\
(208.8)\end{array}$ & $\begin{array}{c}378.9 \\
(253.1)\end{array}$ & $\begin{array}{l}400.7 \\
(250)\end{array}$ & $\begin{array}{c}375.0 \\
(236.2)\end{array}$ & $\begin{array}{l}58.5 \\
(38)\end{array}$ & $\begin{array}{l}78.0 \\
(46)\end{array}$ & $\begin{array}{l}87.8 \\
(57)\end{array}$ & $\begin{array}{l}112.4 \\
(59.7)\end{array}$ & $\begin{array}{l}125.8 \\
(81.3)\end{array}$ & $\begin{array}{l}109.1 \\
(63.1)\end{array}$ & $\begin{array}{c}243.7 \\
(130.5)\end{array}$ \\
\hline LNFEE & $\begin{array}{c}5.25 \\
(5.15)\end{array}$ & $\begin{array}{c}5.22 \\
(5.14)\end{array}$ & $\begin{array}{c}5.48 \\
(5.34)\end{array}$ & $\begin{array}{c}5.57 \\
(5.53)\end{array}$ & $\begin{array}{c}5.61 \\
(5.52)\end{array}$ & $\begin{array}{c}5.52 \\
(5.46)\end{array}$ & $\begin{array}{c}3.63 \\
(3.64)\end{array}$ & $\begin{array}{c}3.82 \\
(3.83)\end{array}$ & $\begin{array}{c}4.04 \\
(4.04)\end{array}$ & $\begin{array}{c}4.14 \\
(4.09)\end{array}$ & $\begin{array}{l}4.37 \\
(4.4)\end{array}$ & $\begin{array}{c}4.16 \\
(4.15)\end{array}$ & $\begin{array}{c}4.85 \\
(4.87)\end{array}$ \\
\hline LNTA & $\begin{array}{c}4.55 \\
(4.87)\end{array}$ & $\begin{array}{c}4.38 \\
(4.59)\end{array}$ & $\begin{array}{c}4.62 \\
(4.95)\end{array}$ & $\begin{array}{c}4.35 \\
(4.57)\end{array}$ & $\begin{array}{c}4.41 \\
(4.61)\end{array}$ & $\begin{array}{c}4.42 \\
(4.65)\end{array}$ & $\begin{array}{c}0.92 \\
(0.99)\end{array}$ & $\begin{array}{c}1.34 \\
(1.68)\end{array}$ & $\begin{array}{c}1.82 \\
(2.22)\end{array}$ & $\begin{array}{c}1.70 \\
(2.04)\end{array}$ & $\begin{array}{l}1.79 \\
(2.06)\end{array}$ & $\begin{array}{l}1.68 \\
(2)\end{array}$ & $\begin{array}{c}3.07 \\
(3.45)\end{array}$ \\
\hline INVREC & $\begin{array}{c}0.22 \\
(0.15)\end{array}$ & $\begin{array}{l}0.27 \\
(0.2)\end{array}$ & $\begin{array}{l}0.26 \\
(0.2)\end{array}$ & $\begin{array}{c}0.20 \\
(0.14)\end{array}$ & $\begin{array}{c}0.26 \\
(0.21)\end{array}$ & $\begin{array}{c}\mathbf{0 . 2 3} \\
(\mathbf{0 . 1 7})\end{array}$ & $\begin{array}{c}0.20 \\
(0.12)\end{array}$ & $\begin{array}{c}0.25 \\
(0.16)\end{array}$ & $\begin{array}{c}0.30 \\
(0.24)\end{array}$ & $\begin{array}{c}0.25 \\
(0.18)\end{array}$ & $\begin{array}{c}0.28 \\
(0.22)\end{array}$ & $\begin{array}{c}0.27 \\
(0.19)\end{array}$ & $\begin{array}{c}0.25 \\
(0.18)\end{array}$ \\
\hline LOSS (\%) & 0.42 & 0.42 & 0.38 & 0.53 & 0.50 & 0.49 & 0.80 & 0.66 & 0.58 & 0.67 & 0.70 & 0.68 & 0.58 \\
\hline $\mathrm{ROA}$ & $\begin{array}{l}-0.05 \\
(0.01)\end{array}$ & $\begin{array}{l}-0.09 \\
(0.01)\end{array}$ & $\begin{array}{l}-0.06 \\
(0.02)\end{array}$ & $\begin{array}{l}-0.18 \\
(-0.01)\end{array}$ & $\begin{array}{c}-0.11 \\
(0)\end{array}$ & $\begin{array}{c}-0.13 \\
(0)\end{array}$ & $\begin{array}{l}-2.78 \\
(-0.41)\end{array}$ & $\begin{array}{l}-9.02 \\
(-0.11)\end{array}$ & $\begin{array}{c}-5.58 \\
(-0.04)\end{array}$ & $\begin{array}{l}-16.73 \\
(-0.14)\end{array}$ & $\begin{array}{l}-3.36 \\
(-0.17)\end{array}$ & $\begin{array}{c}-9.66 \\
(-0.14)\end{array}$ & $\begin{array}{c}-4.84 \\
(-0.04)\end{array}$ \\
\hline$L E V$ & $\begin{array}{c}0.48 \\
(0.43)\end{array}$ & $\begin{array}{c}0.61 \\
(0.44)\end{array}$ & $\begin{array}{c}0.57 \\
(0.47)\end{array}$ & $\begin{array}{c}0.49 \\
(0.37)\end{array}$ & $\begin{array}{l}0.56 \\
(0.4)\end{array}$ & $\begin{array}{c}0.53 \\
(0.41)\end{array}$ & $\begin{array}{c}4.17 \\
(0.84)\end{array}$ & $\begin{array}{l}33.17 \\
(0.7)\end{array}$ & $\begin{array}{c}6.21 \\
(0.51)\end{array}$ & $\begin{array}{c}9.26 \\
(0.57)\end{array}$ & $\begin{array}{l}9.90 \\
(0.6)\end{array}$ & $\begin{array}{l}11.04 \\
(0.59)\end{array}$ & $\begin{array}{c}5.72 \\
(0.47)\end{array}$ \\
\hline$N B S$ & $\begin{array}{c}0.44 \\
(0)\end{array}$ & $\begin{array}{c}0.43 \\
(0)\end{array}$ & $\begin{array}{c}0.44 \\
(0)\end{array}$ & $\begin{array}{c}0.31 \\
(0)\end{array}$ & $\begin{array}{c}0.37 \\
(0)\end{array}$ & $\begin{array}{c}\mathbf{0 . 3 6} \\
(\mathbf{0})\end{array}$ & $\begin{array}{c}0.19 \\
(0)\end{array}$ & $\begin{array}{c}0.25 \\
(0)\end{array}$ & $\begin{array}{c}0.27 \\
(0)\end{array}$ & $\begin{array}{c}0.28 \\
(0)\end{array}$ & $\begin{array}{c}0.21 \\
(0)\end{array}$ & $\begin{array}{c}0.25 \\
(0)\end{array}$ & $\begin{array}{c}\mathbf{0 . 3 0} \\
(\mathbf{0})\end{array}$ \\
\hline$N A S$ & $\begin{array}{c}0.22 \\
(0.18)\end{array}$ & $\begin{array}{l}0.32 \\
(0.2)\end{array}$ & $\begin{array}{c}0.26 \\
(0.24)\end{array}$ & $\begin{array}{c}0.23 \\
(0.18)\end{array}$ & $\begin{array}{c}0.25 \\
(0.21)\end{array}$ & $\begin{array}{c}0.25 \\
(0.19)\end{array}$ & $\begin{array}{c}0.13 \\
(0.07)\end{array}$ & $\begin{array}{c}0.15 \\
(0.11)\end{array}$ & $\begin{array}{c}0.19 \\
(0.14)\end{array}$ & $\begin{array}{c}0.18 \\
(0.13)\end{array}$ & $\begin{array}{c}0.16 \\
(0.12)\end{array}$ & $\begin{array}{c}0.17 \\
(\mathbf{0 . 1 3})\end{array}$ & $\begin{array}{c}0.21 \\
(0.16)\end{array}$ \\
\hline CONCERN (\%) & 0.07 & 0.08 & 0.08 & 0.08 & 0.07 & 0.08 & 0.70 & 0.51 & 0.33 & 0.41 & 0.42 & 0.42 & 0.25 \\
\hline NEWAUD (\%) & 0.11 & 0.06 & 0.07 & 0.05 & 0.05 & 0.05 & 0.12 & 0.14 & 0.16 & 0.17 & 0.17 & 0.16 & 0.11 \\
\hline $\boldsymbol{B U S Y}(\%)$ & 0.68 & 0.65 & 0.72 & 0.75 & 0.72 & 0.73 & 0.69 & 0.68 & 0.68 & 0.65 & 0.64 & 0.66 & 0.69 \\
\hline LNSAL & $\begin{array}{c}3.11 \\
(3.09)\end{array}$ & $\begin{array}{l}3.11 \\
(3.1)\end{array}$ & $\begin{array}{c}3.16 \\
(3.13)\end{array}$ & $\begin{array}{c}3.24 \\
(3.23)\end{array}$ & $\begin{array}{c}3.28 \\
(3.27)\end{array}$ & $\begin{array}{c}3.22 \\
(3.22)\end{array}$ & $\begin{array}{c}3.12 \\
(3.12)\end{array}$ & $\begin{array}{c}3.09 \\
(3.09)\end{array}$ & $\begin{array}{c}3.14 \\
(3.13)\end{array}$ & $\begin{array}{c}3.23 \\
(3.23)\end{array}$ & $\begin{array}{c}3.33 \\
(3.35)\end{array}$ & $\begin{array}{c}3.24 \\
(3.24)\end{array}$ & $\begin{array}{c}3.23 \\
(\mathbf{3 . 2 3})\end{array}$ \\
\hline LNBIG4 & $\begin{array}{c}5.35 \\
(6.91) \\
\end{array}$ & $\begin{array}{c}0.63 \\
(0.41) \\
\end{array}$ & $\begin{array}{c}0.53 \\
(0.29) \\
\end{array}$ & $\begin{array}{c}0.29 \\
(0.29) \\
\end{array}$ & $\begin{array}{c}0.29 \\
(0.29) \\
\end{array}$ & $\begin{array}{c}0.48 \\
(0.29) \\
\end{array}$ & & & & na & & & \\
\hline
\end{tabular}

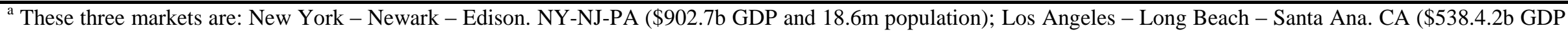
and $12.7 \mathrm{~m}$ population) and Chicago - Naperville - Joliet. IL-IN-WI (\$405.6b GDP and 9.3m population). 
Table 2

Audit Fee Sample Pearson Correlations Matrix ( $p$-values)

\begin{tabular}{|c|c|c|c|c|c|c|c|c|c|c|c|c|c|c|}
\hline Variables & $\begin{array}{c}L N \\
G D P \\
\end{array}$ & LNFEE & BIG4 & LNTA & $\begin{array}{l}\text { INV- } \\
\text { REC }\end{array}$ & LOSS & ROA & $L E V$ & $N B S$ & $N A S$ & $\begin{array}{l}\text { CON- } \\
\text { CERN }\end{array}$ & $\begin{array}{c}N E W- \\
A U D\end{array}$ & $B U S Y$ & LNSAL \\
\hline LNFEE & $\begin{array}{c}0.056 \\
(\mathrm{p}<.001)\end{array}$ & & & & & & & & & & & & & \\
\hline BIG4 & $\begin{array}{l}-0.139 \\
(p<.001)\end{array}$ & $\begin{array}{c}\mathbf{0 . 5 9 2} \\
(\mathrm{p}<.001)\end{array}$ & & & & & & & & & & & & \\
\hline LNTA & $\begin{array}{l}-0.048 \\
(p<.001)\end{array}$ & $\begin{array}{c}\mathbf{0 . 7 6 1} \\
(\mathrm{p}<.001)\end{array}$ & $\begin{array}{c}\mathbf{0 . 5 9 3} \\
(p<.001)\end{array}$ & & & & & & & & & & & \\
\hline INVREC & $\begin{array}{c}0.052 \\
(\mathrm{p}<.001)\end{array}$ & $\begin{array}{l}0.020 \\
(0.079)\end{array}$ & $\begin{array}{l}-0.075 \\
(\mathrm{p}<.001)\end{array}$ & $\begin{array}{c}0.039 \\
(\mathrm{p}<.001)\end{array}$ & & & & & & & & & & \\
\hline LOSS & $\begin{array}{c}0.060 \\
(\mathrm{p}<.001)\end{array}$ & $\begin{array}{c}-0.232 \\
(\mathrm{p}<.001)\end{array}$ & $\begin{array}{l}-0.192 \\
(\mathrm{p}<.001)\end{array}$ & $\begin{array}{l}-0.384 \\
(p<.001)\end{array}$ & $\begin{array}{l}-0.243 \\
(\mathrm{p}<.001)\end{array}$ & & & & & & & & & \\
\hline ROA & $\begin{array}{l}-0.004 \\
(0.759)\end{array}$ & $\begin{array}{c}0.041 \\
(\mathrm{p}<.001)\end{array}$ & $\begin{array}{l}0.032 \\
(0.006)\end{array}$ & $\begin{array}{c}0.117 \\
(\mathrm{p}<.001)\end{array}$ & $\begin{array}{l}0.028 \\
(0.018)\end{array}$ & $\begin{array}{l}-0.031 \\
(0.007)\end{array}$ & & & & & & & & \\
\hline$L E V$ & $\begin{array}{l}0.001 \\
(0.959)\end{array}$ & $\begin{array}{l}-0.090 \\
(\mathrm{p}<.001)\end{array}$ & $\begin{array}{c}-0.058 \\
(\mathrm{p}<.001)\end{array}$ & $\begin{array}{l}-0.212 \\
(p<.001)\end{array}$ & $\begin{array}{l}-0.045 \\
(\mathrm{p}<.001)\end{array}$ & $\begin{array}{c}0.045 \\
(\mathrm{p}<.001)\end{array}$ & $\begin{array}{l}-0.335 \\
(p<.001)\end{array}$ & & & & & & & \\
\hline$N B S$ & $\begin{array}{c}-0.037 \\
(0.001)\end{array}$ & $\begin{array}{c}0.196 \\
(\mathrm{p}<.001)\end{array}$ & $\begin{array}{c}0.106 \\
(\mathrm{p}<.001)\end{array}$ & $\begin{array}{c}0.240 \\
(\mathrm{p}<.001)\end{array}$ & $\begin{array}{c}0.085 \\
(\mathrm{p}<.001)\end{array}$ & $\begin{array}{l}-0.155 \\
(\mathrm{p}<.001)\end{array}$ & $\begin{array}{l}0.018 \\
(0.126)\end{array}$ & $\begin{array}{c}-0.032 \\
(0.007)\end{array}$ & & & & & & \\
\hline$N A S$ & $\begin{array}{l}-0.024 \\
(0.039)\end{array}$ & $\begin{array}{l}0.028 \\
(0.016)\end{array}$ & $\begin{array}{c}0.120 \\
(\mathrm{p}<.001)\end{array}$ & $\begin{array}{c}0.168 \\
(\mathrm{p}<.001)\end{array}$ & $\begin{array}{l}0.027 \\
(0.02)\end{array}$ & $\begin{array}{l}-0.079 \\
(\mathrm{p}<.001)\end{array}$ & $\begin{array}{l}0.020 \\
(0.093)\end{array}$ & $\begin{array}{l}-0.032 \\
(0.007)\end{array}$ & $\begin{array}{c}0.051 \\
(\mathrm{p}<.001)\end{array}$ & & & & & \\
\hline CONCERN & $\begin{array}{c}0.013 \\
(0.27)\end{array}$ & $\begin{array}{l}-0.429 \\
(p<.001)\end{array}$ & $\begin{array}{l}-0.395 \\
(p<.001)\end{array}$ & $\begin{array}{c}-\mathbf{- 0 . 6 1 2} \\
(p<.001)\end{array}$ & $\begin{array}{l}-0.071 \\
(p<.001)\end{array}$ & $\begin{array}{c}0.378 \\
(p<.001)\end{array}$ & $\begin{array}{l}-0.058 \\
(p<.001)\end{array}$ & $\begin{array}{c}0.100 \\
(\mathrm{p}<.001)\end{array}$ & $\begin{array}{l}-0.153 \\
(p<.001)\end{array}$ & $\begin{array}{l}-0.126 \\
(p<.001)\end{array}$ & & & & \\
\hline NEWAUD & $\begin{array}{c}0.030 \\
(0.01)\end{array}$ & $\begin{array}{l}-0.127 \\
(\mathrm{p}<.001)\end{array}$ & $\begin{array}{l}-0.174 \\
(\mathrm{p}<.001)\end{array}$ & $\begin{array}{l}-0.103 \\
(p<.001)\end{array}$ & $\begin{array}{l}0.033 \\
(0.004)\end{array}$ & $\begin{array}{c}0.041 \\
(\mathrm{p}<.001)\end{array}$ & $\begin{array}{l}0.001 \\
(0.912)\end{array}$ & $\begin{array}{c}0.016 \\
(0.16)\end{array}$ & $\begin{array}{l}-0.004 \\
(0.755)\end{array}$ & $\begin{array}{l}-0.036 \\
(0.002)\end{array}$ & $\begin{array}{c}0.095 \\
(\mathrm{p}<.001)\end{array}$ & & & \\
\hline BUSY & $\begin{array}{l}-0.012 \\
(0.315)\end{array}$ & $\begin{array}{c}0.124 \\
(\mathrm{p}<.001)\end{array}$ & $\begin{array}{c}0.077 \\
(\mathrm{p}<.001)\end{array}$ & $\begin{array}{c}0.061 \\
(\mathrm{p}<.001)\end{array}$ & $\begin{array}{l}-0.135 \\
(\mathrm{p}<.001)\end{array}$ & $\begin{array}{c}0.053 \\
(\mathrm{p}<.001)\end{array}$ & $\begin{array}{l}-0.010 \\
(0.379)\end{array}$ & $\begin{array}{c}0.019 \\
(0.11)\end{array}$ & $\begin{array}{l}-0.043 \\
(p<.001)\end{array}$ & $\begin{array}{c}-0.027 \\
(0.019)\end{array}$ & $\begin{array}{l}0.011 \\
(0.344)\end{array}$ & $\begin{array}{l}-0.014 \\
(0.244)\end{array}$ & & \\
\hline LNSAL & $\begin{array}{c}\mathbf{0 . 6 3 0} \\
(\mathrm{p}<.001)\end{array}$ & $\begin{array}{c}0.163 \\
(\mathrm{p}<.001)\end{array}$ & $\begin{array}{l}-0.077 \\
(p<.001)\end{array}$ & $\begin{array}{c}-0.008 \\
(0.466)\end{array}$ & $\begin{array}{c}-0.030 \\
(0.01)\end{array}$ & $\begin{array}{c}0.086 \\
(p<.001)\end{array}$ & $\begin{array}{r}-0.003 \\
(0.821)\end{array}$ & $\begin{array}{c}-0.006 \\
(0.61)\end{array}$ & $\begin{array}{l}-0.086 \\
(p<.001)\end{array}$ & $\begin{array}{l}-0.069 \\
(p<.001)\end{array}$ & $\begin{array}{r}-0.015 \\
(0.202)\end{array}$ & $\begin{array}{r}-0.009 \\
(0.433)\end{array}$ & $\begin{array}{l}0.004 \\
(0.724)\end{array}$ & \\
\hline LNBIG4 & $\begin{array}{l}-0.275 \\
(p<.001)\end{array}$ & $\begin{array}{c}0.175 \\
(\mathrm{p}<.001)\end{array}$ & $\begin{array}{c}0.318 \\
(\mathrm{p}<.001)\end{array}$ & $\begin{array}{c}0.193 \\
(p<.001)\end{array}$ & $\begin{array}{c}-0.026 \\
(0.025)\end{array}$ & $\begin{array}{l}-0.062 \\
(p<.001)\end{array}$ & $\begin{array}{l}0.010 \\
(0.381)\end{array}$ & $\begin{array}{c}-0.019 \\
(0.11)\end{array}$ & $\begin{array}{c}0.064 \\
(\mathrm{p}<.001)\end{array}$ & $\begin{array}{c}0.049 \\
(\mathrm{p}<.001)\end{array}$ & $\begin{array}{l}-0.135 \\
(p<.001)\end{array}$ & $\begin{array}{l}-0.049 \\
(\mathrm{p}<.001)\end{array}$ & $\begin{array}{l}0.017 \\
(0.155)\end{array}$ & $\begin{array}{l}-0.121 \\
(\mathrm{p}<.001)\end{array}$ \\
\hline
\end{tabular}


Table 3

Results of Multivariate Regression of Audit Fees on its Determinants

\begin{tabular}{|c|c|c|c|c|}
\hline \multirow{3}{*}{ Parameters } & \multirow{3}{*}{$\begin{array}{l}\text { Predicted } \\
\text { sign }\end{array}$} & \multicolumn{3}{|c|}{ Regression Estimates ( $t$-stats) } \\
\hline & & Eq. (8) & Eq. (10) & Modif. eq. (10) \\
\hline & & (1) & (2) & (3) \\
\hline \multicolumn{5}{|c|}{ Section A: Test and Market Specific Control Variables } \\
\hline BIG4 & + & $\begin{array}{c}0.999 \\
(4.09 * * *)\end{array}$ & $\begin{array}{l}-3.058 \\
\left(-4.89^{\#}\right)\end{array}$ & $\begin{array}{l}-0.276 \\
(-0.64)\end{array}$ \\
\hline LNGDP & + & $\begin{array}{c}0.130 \\
\left(9.73^{* * *}\right)\end{array}$ & $\begin{array}{c}0.153 \\
(7.82 * * *)\end{array}$ & $\begin{array}{c}0.060 \\
\left(4.51^{* * *}\right)\end{array}$ \\
\hline$B I G 4 * L N G D P$ & - & $\begin{array}{l}\mathbf{- 0 . 0 3 1} \\
(-1.58\end{array}$ & $\begin{array}{c}-0.125 \\
(-5.08 * * *)\end{array}$ & $\begin{array}{l}-\mathbf{- 0 . 0 3 9} \\
(-1.84 *)\end{array}$ \\
\hline LNSAL & + & na & $\begin{array}{c}-0.312 \\
(-1.44)\end{array}$ & $n a^{\S}$ \\
\hline$B I G 4 * L N S A L$ & + & na & $\begin{array}{c}1.609 \\
(6.89 * * *)\end{array}$ & $\begin{array}{c}0.421 \\
\left(3.10^{* * *}\right)\end{array}$ \\
\hline$B I G 4 * L N B I G 4$ & + & $\begin{array}{r}0.014 \\
(0.97) \\
\end{array}$ & $\begin{array}{c}0.006 \\
(0.46) \\
\end{array}$ & $\begin{array}{c}0.006 \\
(0.46) \\
\end{array}$ \\
\hline \multicolumn{5}{|c|}{ Section B: Client Specific Control Variables } \\
\hline LNTA & + & $\begin{array}{c}0.331 \\
(38.97 * * *)\end{array}$ & $\begin{array}{c}0.331 \\
(39.25 * *)\end{array}$ & $\begin{array}{c}0.330 \\
(38.99 * * *)\end{array}$ \\
\hline INVREC & + & $\begin{array}{c}0.146 \\
(2.74 * *)\end{array}$ & $\begin{array}{c}0.175 \\
(3.29 * * *)\end{array}$ & $\begin{array}{c}0.177 \\
\left(3.30^{* * *}\right)\end{array}$ \\
\hline LOSS & + & $\begin{array}{c}0.120 \\
\left(5.67^{* * *}\right)\end{array}$ & $\begin{array}{c}0.115 \\
(5.48 * * *)\end{array}$ & $\begin{array}{c}0.110 \\
\left(5.19^{* * *}\right)\end{array}$ \\
\hline $\boldsymbol{R O A}$ & - & $\begin{array}{c}-0.0002 \\
\left(-2.15^{*}\right)\end{array}$ & $\begin{array}{c}-0.0002 \\
\left(-2.15^{*}\right)\end{array}$ & $\begin{array}{c}-0.0002 \\
(-2.10 *)\end{array}$ \\
\hline$L E V$ & + & $\begin{array}{c}0.001 \\
\left(2.51^{* *}\right)\end{array}$ & $\begin{array}{c}0.001 \\
\left(2.50^{* *}\right)\end{array}$ & $\begin{array}{c}0.001 \\
\left(2.59^{* *}\right)\end{array}$ \\
\hline$N B S$ & + & $\begin{array}{c}0.085 \\
\left(4.17^{* * *}\right)\end{array}$ & $\begin{array}{c}0.091 \\
(4.47 * * *)\end{array}$ & $\begin{array}{c}0.094 \\
\left(4.61^{* * *}\right)\end{array}$ \\
\hline$N A S$ & $?$ & $\begin{array}{c}-0.294 \\
(-2.86 * *)\end{array}$ & $\begin{array}{c}-0.279 \\
(-2.83 * *)\end{array}$ & $\begin{array}{c}-0.284 \\
(-2.82 * *)\end{array}$ \\
\hline CONCERN & + & $\begin{array}{c}0.146 \\
\left(5.17^{* * *}\right)\end{array}$ & $\begin{array}{c}0.154 \\
(5.48 * * *)\end{array}$ & $\begin{array}{c}0.158 \\
\left(5.63^{* * *}\right)\end{array}$ \\
\hline NEWAUD & $?$ & $\begin{array}{l}-0.061 \\
(-2.08 *)\end{array}$ & $\begin{array}{l}-0.050 \\
\left(-1.70^{\dagger}\right)\end{array}$ & $\begin{array}{l}-0.059 \\
(-2.03 *)\end{array}$ \\
\hline BUSY & + & $\begin{array}{c}0.144 \\
\left(6.13^{* * *}\right)\end{array}$ & $\begin{array}{c}0.139 \\
(5.97 * * *)\end{array}$ & $\begin{array}{c}0.144 \\
\left(6.17^{* * *}\right)\end{array}$ \\
\hline Intercept & $?$ & $\begin{array}{c}1.180 \\
\left(6.51^{* * *}\right)\end{array}$ & $\begin{array}{c}1.939 \\
\left(3.53^{* * *}\right) \\
\end{array}$ & $\begin{array}{c}5.774 \\
(31.68 * * *) \\
\end{array}$ \\
\hline Industry Dummies & & YES & YES & YES \\
\hline Year Dummies & & YES & YES & YES \\
\hline Number of observations & & 7416 & 7416 & 7416 \\
\hline Ajusted $R^{2}$ & & 0.708 & 0.713 & 0.704 \\
\hline
\end{tabular}




\section{Table 3 (cont'd)}

$T^{*},{ }^{* * * * * * *}$ Significant at the $10 \%, 5 \%, 1 \%$ and $0.1 \%$ or better significance level respectively (one-tailed where signs are predicted, two-tailed otherwise); $t$-statistics based on heteroskedasticity-consistent standard errors which are robust (i.e., clustered standard errors) to within client-firm correlation.

${ }^{\#}$ Significant at the $0.1 \%$ or better (two-tailed) but of different sign than predicted.

${ }^{\S}$ Structured model: coefficient on $L N S A L$ is set equal to 1 by deflating audit fees by MSAyear specific hourly auditor salary estimate. 